\title{
ARTIFICIAL NEURAL NETWORK DALAM MENENTUKAN GRADING HISTOPATOLOGI KANKER PAYUDARA
}

\author{
Agoes Santika Hyperastuty*1, Anny Setijo R ${ }^{2}$, Riries R. ${ }^{3}$ \\ ${ }^{1}$ Program Studi S2 Teknobiomedik, Sekolah Pascasarjana Universitas Airlangga, Indonesia \\ ${ }^{2}$ Departmen Patologi Anatomi, Fakultas Kedokteran Universitas Airlangga, Indonesia \\ ${ }^{3}$ Departemen Fisika, Fakultas Sains dan Teknologi Universitas Airlangga, Indonesia \\ e-mail: ${ }^{1}$ ag.santika.com, ${ }^{2}$ Anny_setijorahaju@fst.unair.ac.id, ${ }^{3}$ riries-r@fst.unair.ac.id
}

\begin{abstract}
Abstrak
Kanker payudara adalah jenis tumor ganas utama yang diamati pada wanita dan pengobatan yang efektif tergantung pada diagnosis awalnya. Standar emas pemeriksaan kanker payudara adalah pemeriksaan histopatologis sel kanker. Penentuan kadar pada kanker payudara ditentukan oleh tiga faktor: pleomorfik, pembentukan tubular dan mitosis sel. Dalam tulisan ini mengacu pada formasi pleumorfic dan tubular oleh gambar histopatologi sel payudara. Sistem yang diusulkan terdiri dari empat langkah utama: preprocessing, segmentation, ekstrasi fitur dan identifikasi. Pada proses segmentasi menggunakan metode K-Means Clustering yaitu mengelompokkan data menurut kesamaan warna dan bentuk. Hasil dari K-Means tersebut berupa matrik. Ekstraksi fitur menggunakan Gray level Cooccurence Matrix (GLCM) yaitu tingkat keabuan masing-masing citra yang dilihat dari 4 fiturnya adalah kontras, energi, entropi dan homogenitas. Langkah terakhir adalah identifikasi menggunakan Backpropagation. Beberapa parameter penting akan divariasikan dalam proses ini seperti learning rate dan jumlah node pada hidden layer. Hasil penelitian menunjukkan bahwa fitur ekstraksi dalam 4 fitur adalah akurasi terbaik berdasarkan kelas $81,1 \%$ dan khususnya ketepatannya adalah $80 \%$.

Kata kunci-Histopatologic breast cancer, kmeans, GLCM, Backpropagation
\end{abstract}

\begin{abstract}
Breast cancer is the main malignant type of cancer observed in women and effective treatment depends on the initial diagnosis. The gold standard of breast cancer examination is histopathological examination of cancer cells. Determination of levels in breast cancer is determined by three factors: pleomorphic, tubular formation and cell mitosis. In this paper it refers to pleumorphic and tubular formations by histopathologic images of breast cells. The proposed system consists of four main steps: preprocessing, segmentation, feature extraction and identification. In the process of segmentation using K-Means Clustering method is to group the data according to the similarity of colors and shapes. The result of K-Means is a matrix. Feature extraction using Gray level Cooccurence Matrix (GLCM) is the gray level of each image seen from its 4 features is contrast, energy, entropy and homogeneity. The final step is identification using Backpropagation. Some important parameters will be varied in this process such as the learning rate and the number of nodes in the hidden layer. The results showed that the feature extraction in 4 features was the best accuracy based on $81.1 \%$ grade and in particular the accuracy was $80 \%$.

Index key—Histopatologic breast cancer, kmeans, GLCM, Backpropagation
\end{abstract}




\section{PENDAHULUAN}

Kanker payudara (breast cancer) merupakan salah satu penyebab tertinggi kematian manusia selain kanker mulut rahim (servics). Kasus ini dapat terjadi pada pria dan wanita. Penyakit kanker payudara terbilang penyakit yang paling umum menyerang kaum wanita, meski demikian pria pun memiliki kemungkinan mengalami penyakit ini dengan perbandingan 1 diantara 1000. Kanker payudara merupakan suatu penyakit dimana terjadi pertumbuhan secara berlebihan atau perkembangan tidak terkontrol dari sel-sel (jaringan) payudara (Chintya,2009).

Tercatat sebanyak 1,7 juta wanita didiagnosis mengidap penyakit tersebut. Tidak mengherankan jika kanker payudara menjadi salah satu faktor kematian tertinggi, khususnya bagi wanita. Setiap tahun 2 dari 10.000 wanita di dunia diperkirakan mengalami kanker payudara. Angka kematian yang cukup tinggi akibat kanker payudara dialami oleh negara maju dan negara berkembang. Pada tahun 2013, American Cancer Society menyebutkan di US terdapat 296.980 wanita dan 2.240 pria positif kanker payudara dan 39.620 wanita dan 410 pria meninggal. Data dari departemen kesehatan Indonesia pada tahun 2012 menunjukkan 30\% dari pengidap kanker di Indonesia adalah pengidap kanker payudara. Prevalensi penyakit kanker cukup tinggi. Berdasarkan data Riset Kesehatan Dasar (Riskesdas) tahun 2013, prevalensi tumor/kanker di Indonesia adalah 1.4 per 1000 penduduk, atau sekitar 347.000 orang. (www.depkes.go.id, 2015) Data RSUD Soetomo lima tahun terakhir penderita kanker payudara mencapai 5940 orang

Di Indonesia, Jenis histopalogi kanker payudara yang paling banyak ditemukan adalah jenis Invasif Ductal Carsinoma Mamae. Jenis ini merupakan kelompok tumor ganas epitel yang memiliki karakteristik adanya invasi (infiltrasi) ke jaringan sekitarnya dan ditandai dengan adanya kecendrungan mengalami metastasis yang luas ke tempat lain. Pada umumnya tumor ini adalah adenocarsinoma dan dipercaya berasal dari epitel parenkim

\section{Pengertian Kanker Payudara}

Payudara merupakan kelenjar keringat yang mengalami modifikasi dan berkembang lebih kompleks pada wanita dan rudimenter payudara, khususnya sel-sel yang berasal dari unit duktus lobular terminalis (TDLU). (Tavassoli et al., 2003)

Karsinoma payudara invasif merupakan karsinoma yang umum dijumpai pada wanita. Sekitar $22 \%$ dari seluruh karsinoma pada wanita dan sekitar $26 \%$ ditemukan pada negara maju. Resiko kanker ini terus meningkat sejak awal tahun 1980an terutama di negara berkembang, hal ini disebabkan belum berkembangnya pemeriksaan mammografi untuk deteksi dini kanker ini. (Tavassoli et al., 2003)

Prognosis kanker payudara berhubungan dengan berbagai kondisi klinis yang luas dan berbagai faktor patologik. Grade histologi adalah salah satu faktor penting dalam menentukan prognosis penderita. Terdapat dua Sistem grading yang banyak digunakan dalam beberapa tahun terakhir, yaitu sistem Bloom-Richardson dan sistem Black. (Edinburgh : Mosby, (O2011)

Metode grading dengan menggunakan tiga karakteristik tumor yang akan dievaluasi, yaitu: formasi tubulus dan kelenjar, pleomorfisme inti dan jumlah mitosis. Digunakan sistem skor antar 1-3 dan mengkaji setiap faktor yang memiliki gambaran tertentu. Masing-masing ahli Patologi anatomi memiliki penilaian grading berbeda karena berdasarkan perhitungan menggunakan kemampuan daya penglihatan dan keahlian masing-masing ahli. Jadi penentuannya sangatlah subjektif. Beberapa penelitian menyebutkan bahwa terdapat hubungan antara tingkatan gradasi histologi tumor dengan angka harapan hidup penderita. Hal ini menjadikan gradasi histologi tumor sebagai salah satu faktor penting dalam penilaian prognosis penyakit dan sebagai salah satu pemeriksaan yang harus selalu dilakukan dalam penilaian penyakit. Perkiraan penentuan grading sangatlah penting karena diperlukan untuk menentukan tindakan berikutnya. Untuk membantu para dokter ahli Patologi Anatomi dalam menentukan granding kanker payudara secara cepat perlu dilakukan ekstrasi ciri pada masing-masing sel kanker.

pada pria. Proses perkembangan dimulai pada janin berumur 6 minggu dimana terjadi penebalan lapisan epidermis pada bagian ventral, superfisial dari fasia pektoralis serta 
otot-otot pektoralis mayor dan minor. Penebalan yang terjadi pada venteromedial dari region aksila sampai ke regio inguinal menjadi milk lines dan selanjutnya pada bagian superior berkembang menjadi puting susu dan bagian lain.

Secara fisiologis, payudara mengalami berbagai perubahan yang dipengaruhi oleh hormonal. Pada saat pubertas, estrogen dan progesteron yang dihasilkan oleh ovarium dan pengaruh hipofisa anterior menyebabkan berkembangnya duktus dan asinus. Sesuai dengan siklus menstruasi, terjadi peningkatan estrogen dan progesteron sehingga terjadi proliferasi sel dan retensi cairan. Pada saat kehamilan, terjadi proliferasi sel akibat pengaruh estrogen, progesteron, laktogen plasenta dan prolaktin. Pada saat menyusui terjadi peningkatan produksi prolaktin dan penurunan estrogen dan progesteron, sedangkan pada saat menopause terjadi involusi payudara diikuti dengan berkurangnya jumlah kelenjar.(Liu 1993)

Untuk dapat mengenal perjalanan penyakit kanker payudara dengan baik dan memahami dasar-dasar tindakan operasi pada kanker payudara maka sangat penting mengetahui anatomi payudara itu sendiri.

Kanker payudara adalah kanker yang terjadi pada payudara karena adanya pertumbuhan yang tidak terkendali dari sel-sel kelenjar dan salurannya, sehingga merusak organ atau jaringan sekitar dan melakukan penyebaran ke bagian tubuh yang lain. (Nisman, 2011)

Jaringan payudara tersebut terdiri dari kelenjar susu (kelenjar pembuat air susu), saluran kelenjar (saluran air susu), dan jaringan penunjang payudara. Kanker payudara tidak menyerang kulit payudara yang berfungsi sebagai pembungkus. Kanker payudara menyebabkan sel dan jaringan payudara berubah bentuk menjadi abnormal dan bertambah banyak secara tidak terkendali. (Anwar 2000)

Histologi adalah ilmu yang mempelajari anatomi sel dan jaringan organisme secara mikroskopis. Analisis histologi dilakukan dengan memeriksa irisan tipis dari jaringan di bawah mikroskop cahaya (mikroskop optik) atau mikroskop elektron. Setelah urutan prosedur teknis untuk persiapan jaringan (fiksasi, dehidrasi, clearing, infiltrasi, embedding, sectioning, dan staining), gambar histologi dapat dihasilkan dengan teknik pencitraan yang berbeda-beda, didasarkan pada analisis manual atau otomatis yang dapat dilakukan untuk mendeteksi jaringan yang abnormal. Grading histopatologi umumnya dianggap sebagai standar emas untuk diagnosis klinis kanker dan identifikasi target terapeutik dan prognostik $(\mathrm{He}$, et.al., 2014).

Grading tumor secara histopatologi didasarkan pada derajat diferensiasi dari jaringan tumor. Pada kanker payudara, mengacu pada evaluasi semi-kuantitatif karakteristik morfologi dan merupakan metode yang relatif sederhana dan lowcost. Irisan jaringan tumor diwarnai dengan hematoxylineosin, dinilai oleh ahli patologi anatomi yang terlatih menggunakan protokol standar (Rakha, et.al., 2010).

Grading tumor tidak sama dengan stadium kanker. Stadium kanker mengacu pada ukuran dan/ atau batas lokasi tumor primer dan apakah sel kanker telah menyebar di dalam tubuh. Stadium kanker didasarkan pada faktorfaktor seperti lokasi tumor primer, ukuran tumor, keterlibatan kelenjar getah bening regional (penyebaran kanker ke kelenjar getah bening di dekatnya), dan jumlah tumor yang hadir (Rakha, et.al., 2010). Sedangkan grading tumor merupakan deskripsi tumor yang didasarkan pada bagaimana kondisi abnormal sel-sel tumor dan jaringan tumor yang terlihat di bawah mikroskop.

\section{Citra Digital}

Citra Digital merupakan representasi dari fungsi intensitas cahaya dalam bidang dua dimensi. Berdasarkan jenis warnanya, citra dapat dikelompokkan menjadi tiga jenis yaitu citra RGB, citra grayscale, dan citra biner. 
Citra RGB

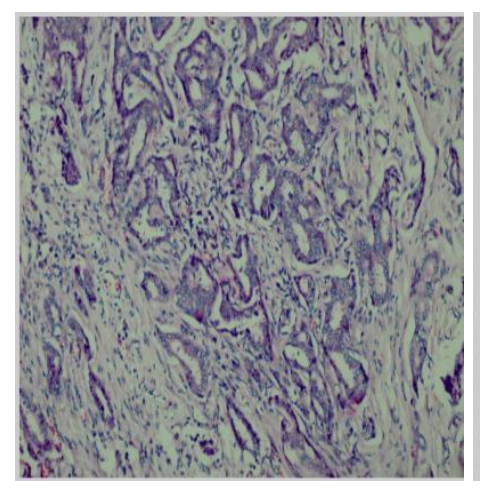

Citra Grayscale

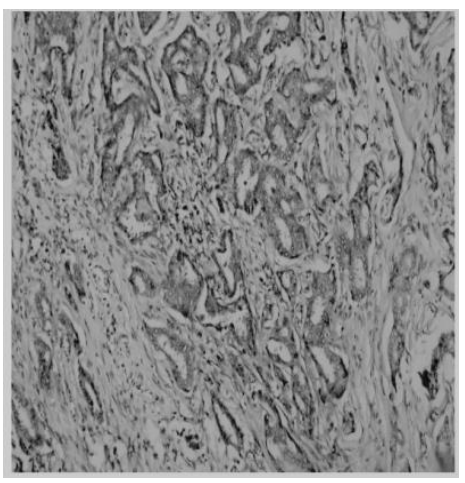

Citra Biner

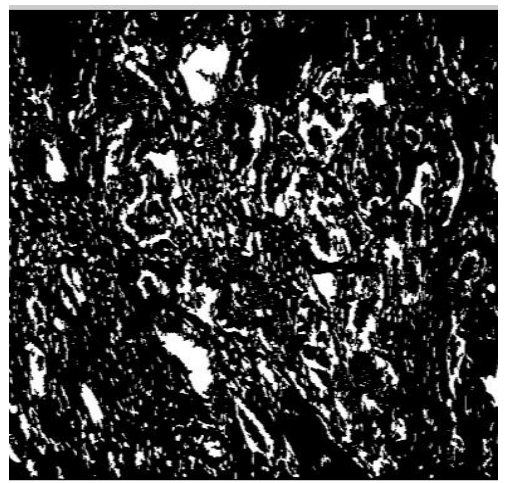

Gambar 2.8. Jenis Citra digital

Citra RGB merupakan citra yang tersusun oleh tiga kanal warna yaitu kanal merah, kanal hijau, dan kanal biru. Pada citra RGB 24-bit, masing-masing kanal warna memiliki nilai intensitas piksel dengan kedalaman bit sebesar 8-bit yang artinya memiliki variasi warna sebanyak $2^{\wedge} 8=256$ derajat warna $(0$ s.d 255). Setiap piksel pada citra RGB memiliki nilai intensitas yang merupakan kombinasi dari nilai $\mathrm{R}, \mathrm{G}$, dan B. Variasi warna pada setiap piksel pada citra RGB adalah sebanyak $256 \mathrm{x}$ $256 \times 256=16.777 .216$.

Sedangkan citra grayscale merupakan citra yang hanya memiliki satu kanal warna. Pada citra grayscale 8-bit, setiap piksel memiliki nilai intensitas warna yang memiliki variasi sebanyak $2^{\wedge} 8=256$ derajat warna $(0$ s.d 255). Nilai intensitas pada citra ini merupakan representasi dari derajat keabuan di mana nilai 0 menyatakan warna hitam sempurna dan nilai 255 menyatakan warna putih sempurna. Nilai intensitas antara 0 s.d 255 merupakan warna abu-abu.

Sama seperti citra grayscale, citra biner juga merupakan citra yang hanya memiliki satu kanal warna. Citra biner memiliki kedalaman bit sebesar 1-bit. Nilai intensitas warna pada setiap piksel citra biner dibagi menjadi $2^{\wedge} 1=2$ warna yaitu warna hitam yang dinyatakan oleh nilai 0 dan warna putih yang dinyatakan oleh nilai 1

\section{Segmentasi K-Means}

Segmentasi citra merupakan bagian dari proses pengolahan citra. Proses segmentasi citra ini lebih banyak merupakan suatu proses pra pengolahan pada sistem pengenalan objek dalam citra. Segmentasi citra (image segmentation) mempunyai arti membagi suatu citra menjadi wilayah-wilayah yang homogen berdasarkan kriteria keserupaan yang tertentu antara tingkat keabuan suatu piksel dengan tingkat keabuan piksel - piksel tetangganya, kemudian hasil dari proses segmentasi ini akan digunakan untuk proses tingkat tinggi lebih lanjut yang dapat dilakukan terhadap suatu citra, misalnya proses klasifikasi citra dan proses identifikasi objek. Salah satu segmentasi yang digunakan dalam penelitian ini adalah segmentasi warna.

Segmentasi warna merupakan salah satu metode segmentasi citra yang memisahkan antara objek dengan background berdasarkan ciri warna tertentu dari objek tersebut. Proses segmentasi warna, salah satunya dapat dilakukan dengan cara mengkonversi ruang warna citra yang semula RGB (Red, Green, Blue) menjadi ruang warna HSV (Hue, Saturation, Value). Komponen Hue merupakan komponen yang merepresentasikan warna dari berbagai panjang gelombang cahaya. $\mathrm{K}$-means merupakan salah satu metode data clustering non hirarki yang berusaha mempartisi data yang ada ke dalam satu 
atau lebih cluster/kelompok. Metode ini mempartisi data ke dalam cluster/kelompok sehingga data yang memiliki karakteristik yang sama dikelompokkan ke dalam satu cluster yang sama dan data yang mempunyai karakteristik yang berbeda dikelompokkan ke dalam kelompok yang lain.

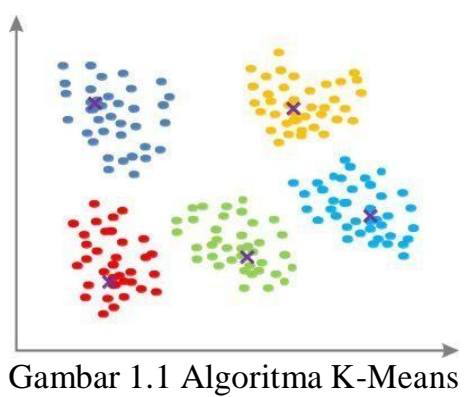

Algoritma untuk melakukan k-means clustering adalah sebagai berikut:

1. Tentukan jumlah kluster yang diinginkan (k)

2. Tentukan nilai centroids awal secara acak

3. Hitung jarak tiap data terhadap masingmasing centroid

4. Kelompokkan data-data tersebut ke kluster berdasarkan jarak paling dekat (minimum) terhadap sebuah kluster

5. Hitung ulang nilai centroids dengan menghitung nilai rerata (mean) data dari masing-masing kluster

6. Lakukan langkah 3-5 hingga nilai centroids tidak lagi mengalami perubahan Perhitungan jarak antara centroid dengan data dapat dilakukan menggunakan persamaan euclidean distance, cityblock, cosine, correlation, maupun hamming

\section{Ekstrasi Ciri Dengan GLCM}

Ekstraksi ciri merupakan bagian dari teknik pengenalan pola (pattern recognition) yang bertujuan untuk mengambil atau mengekstraksi nilai-nilai unik dari suatu obyek yang membedakan dengan obyek yang lain. Analisis tekstur lazim dimanfaatkan sebagai proses antara untuk melakukan klasifikasi dan interpretasi citra. Suatu proses klasifikasi citra berbasis analisis tekstur pada umumnya membutuhkan tahapan ekstraksi ciri, yang terdiri dari tiga macam metode yaitu metode statistik, metode spaktral dan metode struktural.
Metode GLCM termasuk dalam metode statistik dimana dalam perhitungan statistiknya menggunakan distribusi derajat keabuan (histogram) dengan mengukur tingkat kekontrasan, granularitas, dan kekasaran suatu daerah dari hubungan ketetanggaan antar piksel di dalam citra. Paradigma statistik ini penggunaannya tidak terbatas, sehingga sesuai untuk tekstur-tekstur alami yang tidak terstruktur dari sub pola dan himpunan aturan (mikrostruktur).

Matrix GLCM dihitung dari nilai pixel yang berpasangan dan memiliki nilai intensitas tertentu. Misalkan $\mathrm{d}$ adalah jarak antara dua pixel yaitu $\left(\mathrm{x}_{1}, \mathrm{y}_{1}\right)$ dan $\left(\mathrm{x}_{2}, \mathrm{y}_{2}\right)$ dan $\Theta$ tetha didefinisikan sebagai sudut antara keduanya, maka matrix GLCM merupakan distribusi spasial dari $P_{d \Theta}(i, j)$. Banyak paper menuliskan berbagai versi tentang perhitungan GLCM terutama mengenai masalah sudut yang digunakan. Berikut adalah ilustrasi yang menggambarkan arah sudut dengan jarak 1 pixel dan ada 4 jenis sudut yang digunakan fitur - fitur pada GLCM :

\section{Homogenitas}

Menunjukkan kehomogenan variasi intensitas dalam citra. Persamaan Hommanitas.

$$
\sum_{i_{1}} \sum_{i_{2}} \frac{P_{i_{1}, i_{2}}}{1+\left|i_{1}-i_{2}\right|}
$$

\section{Energi}

Energi merupakan fitur GLCM yang digunakan untuk mengukur konsentrasi pasangan intensitas pada matriks GLCM, dan didefinisikan sebagai harilut.

$$
\sum_{i_{1}} \sum_{i_{2}} p^{2}\left(i_{1}, i_{2}\right)
$$

3. Kontras

$$
\begin{aligned}
& \text { Kontras untuk memperbaiki kontras } \\
& \sum_{i_{1}} \sum_{i_{2}} P_{i_{1} i_{2}}\left(i_{1}-i_{2}\right)^{2} \\
& \text { Entropy } \\
& \text { Menunjukkan ukuran ketidakteraturan } \\
& \text { bentuk: }
\end{aligned}
$$

4. Entropy

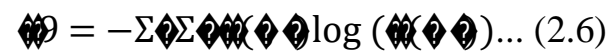




\section{Jaringan Syaraf Tiruan}

Jaringan syaraf tiruan (JST) didefenisikan sebagai susunan dari elemen-elemen penghitung yang disebut neuron atau titik (node) yang saling terhubung guna dimodelkan untuk meniru fungsi otak manusia (Sinambela et al, 2013). Hal paling penting dari konsep jaringan syaraf yaitu adanya proses pembelajaran dengan tujuan utama melakukan pengaturan terhadap bobot-bobot yang ada pada jaringan syaraf, sehingga diperoleh bobot akhir yang tepat sesuai dengan pola data yang dilatih. Selama proses pembelajaran terjadi perbaikan bobot-bobot berdasarkan algoritma tertentu.

Backpropagation merupakan salah satu jenis jaringan syaraf tiruan yang terdiri dari beberapa layer (multilayer) dengan metode pembelajaran terawasi (Supervised Learning). Algoritma pembelajaran error backpropagation merupakan sebuah algoritma jaringan syaraf yang belajar untuk membedakan pola yang tidak bisa dipisahkan secara linier (Anzai, 1946). Setiap unit jaringan backpropagation yang berada di lapisan input terhubung dengan setiap unit yang ada di lapisan tersembunyi (hidden layer) terhubung dengan setiap unit yang ada di lapisan output. Ketika jaringan diberikan pola masukan sebagai pola pelatihan, maka pola tersebut menuju unit-unit lapisan tersembunyi untuk selanjutnya keluaran akan memberikan respon sebagai keluaran jaringan syaraf tiruan. Saat hasil keluaran tidak sesuai dengan yang diharapkan, maka keluaran akan dijalankan mundur (backward) pada lapisan tersembunyi kemudian dari lapisan tersembunyi menuju lapisan masukan.

Setiap unit di dalam layer input pada jaringan backpropagation selalu terhubung dengan setiap unit yang berada pada layer tersembunyi, demikian juga setiap unit pada layer tersembunyi selalu dari banyak lapisan (Sinambela et al, 2013) yaitu:
1. Lapisan input (1 buah), yang terdiri dari 1 hingga $n$ unit input.

2. Lapisan tersembunyi (minimal 1 buah), yang terdiri dari 1 hingga $p$ unit tersembunyi.

Lapisan output (1 buah), yang terdiri dari 1 hingga $m$ unit output.

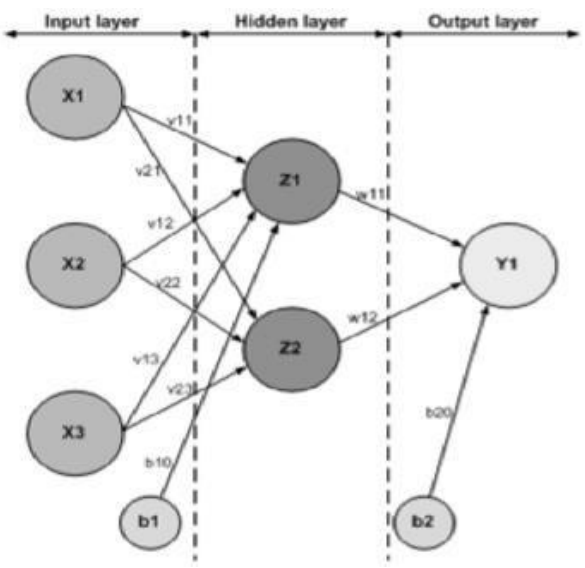

Gambar 1.2. Arsitektur Jaringan

Backpropagation (Sinambela et al, 2013)

\section{Pembuatan GUI}

GUI merupakan tampilan grafis dalam satu atau lebih jendela program yang berisikan komponen, yang dapat memudahkan penggunanya untuk menyelesaikan tugas secara iteratif. Penggunaan GUI tidak perlu membuat script program atau menulis perintah di commond window untuk memecahkan masalah (Stefandi, 2014: 121). Alat (tool) yang digunakan untuk merancang GUI terdiri dari 1 selektor (select) dan 11 tool. Properti pendukung dalam membangun GUI antara lain:

\section{Align Objects}

Berfungsi untuk meluruskan objekobjek yang dipilih dengan menggunakan

koleksi (block) pada perataan vertikal dan horizontal.

2. Menu Editor

Berfungsi untuk menambahkan dan mengedit menu pull down yang dibuat user dan digabungkan ke dalam sebuah figure.

3. Property Inspector

Merupakan bentuk keluaran yang digunakan untuk mengendalikan susunan 
handle graphic (penanganan grafik) yang berfungsi untuk menambah, mengubah hal-hal yang berkaitan dengan objek.

\section{M-file Editor}

Fungsi M-file mirip dengan script file teks dengan eksistensi .m. Fungsi Mfile menyediakan cara sederhana untuk menambah kemampuan Matlab.

\section{Object Browser}

Berfungsi sebagai menu yang berisi informasi tentang tool-tool yang digunakan dalam satu desain. Hal ini akan mempermudah proses terhadap tool-tool tertentu.

\section{METODE PENELITIAN}

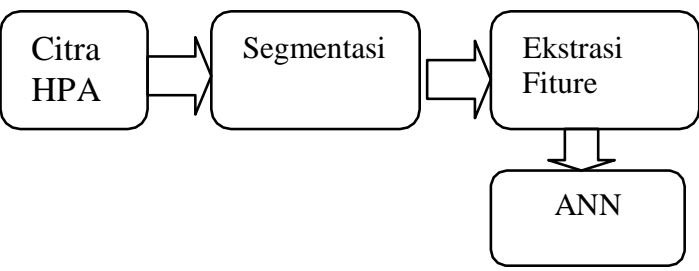

Gambar 3.1 Metodologi Penelitian

Pada penelitian ini menggunakan bahan sediaan histopatologi kanker payudara yang diambil dengan menggunakan mikroskop elektronik dengan perbesaran 40x. Citra yang dihasilkan disimpan dengan dalam bentuk (*.bmp). citra yang disimpan berukuran 2560x1916 piksel. Terdapat 50 data citra grade 1,50 grade 2 dan 50 grade 3 . Hasil dari citra tersebut kemudian di olah menggunakan software matlab 2014b dengan metode K-Means clustering untuk segmentasi citra. Segmentasi citra disini bertujuan untuk mengelompokkan citra sesuai dengan kesamaan warna dan bentuk. Nilai K ditentukan bernilai 3. Setelah ditentukan 3 pembagian kelompok tersebut akhirnya terdapat 3 citra yang berbeda. Kelompok pertama menggambarkan kesamaan warna hitam atau gelap yang menunjukkan kelompok pleumorfik yaitu kesamaan inti sel atau nukleus. Kedua menunjukkan warna putih dan citra terakhir yang melabeli masing-masing inti sel atau nukleus.

Output citra hasil segmentasi berupa matrik yang akan menjadi nilai masukan dari ekstrasi fitur yang menggunakan metode GLCM. GLCM adalah metode statistik yang digunakan untuk menentukan derajat keabuan dari masing-masing citra. Ada 4 parameter yang menentukan masing-masing nilai keluaran GLCM yaitu nilai homogenitas, energi, entrophi dan kontras. Masing-masing nilai tersebut mengambarkan karakteristik dari citra yang berbeda-beda. Homogenitas menunjukkan nilai pola keseragaman inti sel atau nukleus. Energi menunjukkan penyebaran masing-masing sel kanker payudara. Entropi menunjukkan nilai dari keteracakan dari masing-masing intisel atau nukleus. Kontras menunjukkan intensitas warna yang dihasilkan dari masing-masing citra yang dihasilkan. Setelah masing-masing citra mempunyai nilai kita berikan nilai target untuk mengetahui termasuk dalam kelompok grade 1,2,3. Nilai target yang telah ditentukan adalah 0-1.

Untuk memberikan data latih pada ANN masing-masing diberikan nilai target. Nilai target tersebut diberikan supaya ANN mengenali pola masingmasing. Pada grade 1 diberikan target 0 , grade 2 nilai targetnya 0.5 dan grade 3 diberikan nilai target 1 . Dari 50 data citra masing-masing dipilih secara random yang digunakan untuk data testing sebanyak 10 dan 40 data traning. Nilai target ini dimaksudkan melabeli masingmasing kelompok untuk memberikan pelatihan supaya ketika dimasukkan citra baru ANN mampu mengenali citra tersbut sesuai dengan parameter yang ditentukan. Adapun dalam sistem backpropagation, Dalam proses pelatihan jaringan syaraf tiruan 40 data yang diambil kita tentukan learning rate, hidden layer dan epoch. Learning rate adalah laju pembelajaran. Semakin besar nilai learning rate akan berimplikasi pada semakin besar langkah pembelajaran. Jika learning rate diset terlalu besar, algoritma menjadi tidak stabil. Sebaliknya jika learning rate terlalu kecil, algoritma akan konvergen dalam jangka waktu yang sangat lama. Hidden layer adalah menentukan berapa banyaknya proses yang diperlukan untuk running. Semakin besar nilai hidden 
layer semakin lama proses training datanya. Jumlah epoch menunjukkan kemajuan pembelajaran. Untuk nilai bobot dan bias awal dengan bilangan acak kecil. Bobot dan bias ini akan berubah setiap kali ingin membentuk jaringan. Bobot dan bias ini akan berubah setiap kali membentuk jaringan.Pada proses testing kita masukkan data satu per satu untuk dilakukan pengujian dan dilihat angka akurasinya menunjukkan nilai sesuai dengan data training.

\section{HASIL DAN PEMBAHASAN}

Hasil pengambilan gambar dari masingmasing slide histopatologi kancer payudara berupa sepuluh potongan gambar.

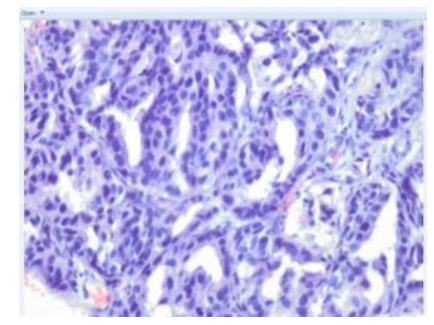

Gambar 4.1. Sediaan grade 1

Setelah itu masuk ke proses pemprosesan citra yaitu dari segmentasi, fiture ekstrasi dan proses pelatihan jaringan menggunakan backpropagation Segmentasi citra

Dari citra asli yang diambil dengan menggunakan mikroskop elektron dengan pembesaran 40x, citra dinormalisasikan. Dengan tujuan agar tidak ada informasi yang hilang ketika diolah dilangkah berikutnya.

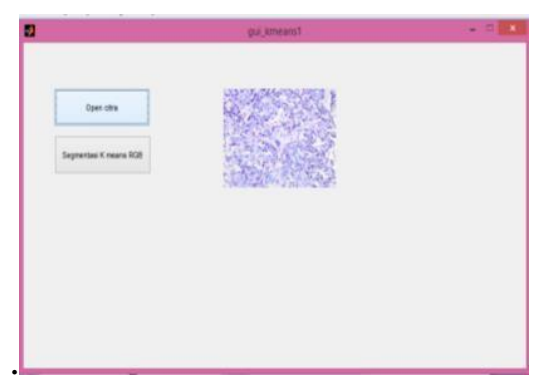

Gambar 4.2. Tampilan GUI
Pada proses pengolahan citra yang dilakukan adalah mengubah citra dari biner menjadi RGB. Pemilihan image dari tiap kanal R,G,B untuk melihat citra yang jelas dan tidak ada noise.

Dari hasil K-Means menunjukkan masingmasing sel mempunyai karakteristik sendiri. Yang menunjukkan nukleus berupa bulatan-bulatan kecil berwarna biru sedangkan yang membentuk formasi tubular ditunjukkan oleh kelompok hitamhitam memanjang.

\section{Ekstrasi Fitur dengan metode GLCM}

Ekstrasi fitur dilakukan pada data latih maupun uji untuk mengetahui ciri

khas yang menggambarkan diagnosa citra. Dalam penelitian ini digunakan metode statistik orde dua yaitu Gray Level Co-occurrence Matrices (GLCM)untuk mengetahui empat fitur tekstur dari citra yaitu energy, entropi, kontras dan entrophy. GLCM digunakan untuk mengetahui probabilitas pasangan piksel yang saling bertetangga dengan tingkat keabuan, jarak, dan sudut tertentu. Penelitian GLCM dilakukan dalam empat arah sudut yaitu yaitu $0^{\circ}, 45^{\circ}, 90^{\circ}, 135^{\circ}$ dengan jarak 1 piksel. Albergsten (2008) menyarankan untuk hanya menggunakan nilai rata-rata fitur tekstur dari keempat sudut jika ingin menghindari ketergantungan arah piksel bertetangga.

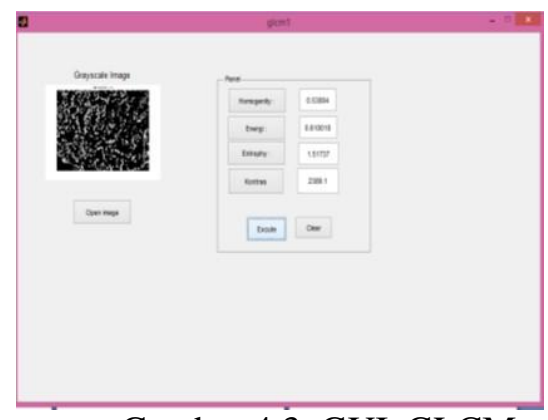

Gambar 4.3. GUI GLCM

Dari image yang sudah tersegmentasi dimasukkan ke GUI ektrasi fitur akan keluar angka homoginitas, energi, kontras dan entrophy yang menunjukkan letak dari pleumorfik. Data tersebut nantinya akan dibuat data pelatihan backpropagation.

\section{Pelatihan Jaringan Backpropagation}

Data yang digunakan dalam pelatihan backpropagation merupakan 
80\% dari keseluruhan data hasil dari GLCM.

Pelatihan backpropagation dalam penelitian ini bertujuan untuk mendapatkan bobot yang mampu menghasilkan perhitungan keluaran sedekat mungkin dengan target sehingga dihasilkan akurasi yang tinggi. Bobot awal yang digunakan dipilih secara acak dengan rentang nilai dari -1 hingga 1. Tahap pelatihan ini dilakukan variasi parameter backpropagation yaitu maksimal epoh, hidden layer, dan learning rate atau laju pembelajaran. Selain variasi parameter dalam pelatihan juga dilakukan variasi input untuk mengetahui fitur tekstur yang benar-benar mudah dikenali oleh backpropagation. Hasil pelatihan backpropagation disajikan pada gambar 5.7. Hasil pelatihan dinyatakan dalam bentuk persentase akurasi. Akurasi pelatihan menyatakan banyaknya kesesuain keluaran selama pelatihan terhadap target atau hasil diagnosa dokter. Akurasi pelatihan juga menggambarkan kemampuan backpropagation untuk mengenali pola yang diberikan. Berdasarkan Lampiran 2, untuk variasi satu input akurasi tertinggi didapatkan dari pelatihan menggunakan Gambar 5.7.dengan MSE sebesar 0,0068. Pengujian Backpropagation tahap pengujian bertujuan untuk mengetahui kemampuan backpropagation yang telah dibangun dan dilatih untuk mengenali pola baru. Selain itu hal ini juga bertujuan untuk mengetahui kemampuan fitur yang digunakan dalam mengidentifikasi citra sediaan histopatologi kanker payudara mulai dari grade $1,2,3$. Data yang digunakan dalam pengujian backpropagation merupakan 20 $\%$ dari keseluruhan masing-masing citra sediaan histopatologi kanker payudara sehingga terdapat 10 grade 1,10 grade 2 dan 10 grade 3 . Pengujian ini menggunakan parameter dan bobot yang sudah

didapatkan dari pelatihan dengan akurasi tertinggi yaitu 10 hidden layer,

laerning rate 1, dan maksumim epoh 10000. Bobot yang telah didapatkan kemudian digunakan di dalam jendela deteksi. Selama proses pengujian ini, satu persatu gambar dimasukkan ke dalam jendela program deteksi yang akan menampilkan nilai fitur sekaligus hasil diagnosa oleh backpropagation. Untuk data pengujian terlampir.

\begin{tabular}{|l|l|l|l|l|l|l|l|l|}
\hline No & $\begin{array}{l}\text { No } \\
\text { gbr }\end{array}$ & Homogenitas & Energi & Entrophy & Kontras & Target & MSE & $\begin{array}{l}\text { E } \\
\text { max }\end{array}$ \\
\hline 1 & A3 & 0.551763 & 0.586215 & $1,49035 \mathrm{E}+05$ & 2285.49 & 0 & 0.05 & 1800 \\
\hline 2 & A8 & 0.537828 & 0.613199 & $1,52648 \mathrm{E}+05$ & 2395.65 & 0 & 0.025 & 2500 \\
\hline 3 & A11 & 0.55211 & 0.582056 & $1,50996 \mathrm{E}+05$ & 2043.84 & 0 & 0.01 & 1500 \\
\hline 4 & A15 & 0.53311 & 0.569358 & $1,52312 \mathrm{E}+05$ & 3447.37 & 0 & 0.027 & 2500 \\
\hline 5 & A20 & 0.517124 & 0.552784 & $1,39441 \mathrm{E}+05$ & 317.795 & 0 & 0.0016 & 700 \\
\hline 6 & A24 & 0.538893 & 0.576552 & $1,48390 \mathrm{E}+04$ & 2937.73 & 0 & 0.07 & 2500 \\
\hline 7 & A29 & 0.538482 & 0.615942 & $1,47524 \mathrm{E}+05$ & 2646.55 & 0 & 0.05 & 1500 \\
\hline 8 & A33 & 0.578258 & 0.624036 & $1,17370 \mathrm{E}+04$ & 1453.29 & 0 & 0.035 & 2500 \\
\hline 9 & A38 & 0.522434 & 0.562793 & $1,46196 \mathrm{E}+05$ & 1510.34 & 0 & 0.09 & 1900 \\
\hline 10 & A42 & 0.527894 & 0.553129 & $1,51681 \mathrm{E}+05$ & 922.96 & 0 & 0.0014 & 250 \\
\hline
\end{tabular}

Dari diatas dapat dilihat masing-masing mempunyai nilai yang hampir sama atau bisa dikatakan rentang nilai sangat kecil. Hal ini sangatlah sulit untuk membuat ANN membuat pembeda antara citra grade 1 dengan yang lain. Untuk itu perlu dilakukan perhitungan statistik untuk membedakan masing-masing gradingnya. Dari data yang ada akan dilakukan uji inova untuk mengetahui standart masing-masing nilai grading.

Tujuan utama dari penelitian ini adalah dapat mengenali citra sediaan kanker payudara sesuai dengan grading masingmasing yaitu grade 1,2,3. Pada penelitianpenelitian sebelumnya sudah dilakukan dengan menggunakan beberapa metode mulai dari metode segmentasi sampai dengan sistem cerdas yang dipakai. Acuan 
jurnal tersebut digunakan untuk membuat identifikasi dengan cara yang mudah dan dapat menghasilkan tingkat akurasi yang tinggi.

Pada penelitian ini, semua citra sediaan histopatologi kanker payudara dilakukan proses segmentasi menggunakan metode K-Means. K-means klustering merupakan metode yang disarankan dalam pengolahan segmentasi citra histopatologi kanker. Karena metode mampu mensegmentasi atau membagi citra berdasarkan kebutuhan. Seperti pada penelitian ini, metode ini mampu mensegmentasi menjadi 3 kelompok sesuai dengan jarak kedekatan centroidnya sehingga komputer mampu mengolah hasil segmentasi dengan cepat dan dapat menghasilkan nilai yang maksimal. Hasil dari segmentasi tersebut berupa matriks yang digunakan untuk inputan pengolahan berikutnya.

$$
\text { Pengolahan ektrasi citra }
$$
menggunakan GLCM(Gray Level CoOcurance Matriks). Input dari GLCM adalah matrik output dari hasil segmentasi. Matrik intensitas co-occurrence adalah suatu matriks yang menggambarkan frekuensi munculnya pasangan dua piksel dengan intensitas tertentu dalam jarak dan arah tertentu dalam citra. Matriks intensitas cooccurance dilambangkan $\mathrm{p}\left(\mathrm{i}_{1}, \mathrm{i}_{2}\right)$ dimana nilai intensitas $i_{1}$ dan pasangan yang berjarak $d$ mempunyai nilai intensitas $i_{2}$ dihitung dan dimasukkan ke dalam kolom ke - $i_{1}$ dan baris ke- $i_{2}$ pada matriks $p\left(i_{1}, i_{2}\right)$. Selanjutnya tiap elemen matriks perlu dinormalisasikan dengan cara membaginya dengan bilangan yang merupakan jumlah total dari pasangan piksel. Nilai-nilai elemen matriks setelah dinormalisasikan kemudian dapat diperlakukan sebagai fungsi probabilitas karena jumlah seluruh elemennya bernilai 1 .

Salah satu sifat tekstur dapat diambil dari statistik nilai intensitas abu-abu dalam citra yaitu rata-rata (mean). Untuk mengesktrak sifat-sifat lain dalam analisis tekstur, matriks co-occurance sangat diperlukan. Beberapa fitur untuk mengukur keteracakan dari distribusi intensitas disebut entropi. Nilai entropi maksimum jika semua elemen $\mathrm{p}\left(\mathrm{i}_{1}, \mathrm{i}_{2}\right)$ sama, yaitu matriks yang berhubungan dengan citra dimana tidak terdapat susunan tertentu dalam pasangan intensitas dengan jarak vektor tertentu(daerah konstan). Fitur lain adalah energi, untuk mengukur konsentrasi pasangan intensitas pada matriks cooccurance. Nilai energi makin membesar jika pasangan piksel yang memenuhi syarat metriks intensitas co-occurance terkonsentrasi pada beberapa koordinat dan mengecil jika letaknya menyebar. Fitur lainnya kontras digunakan untuk mengukur kekuatan perbedaan intensitas dalam citra. Nilai kontras membesar jika variasi intensitas dalam citra dan menurun jika variasi variasinya rendah. Kebalikan dari kontras adalah homogenitas yaitu untuk mengukur kehomogenan variasi intensitas dalam citra. Nilai homoginitas membesar jika variasi intensitas dalam citra mengecil dan sebaliknya mengecil jika variasi intensitas dalam citra membesar. Hal ini dibuktikan dengan data hasil GLCM citra sediaan histopatologi kanker payudara.

Dari masing-masing parameter tersebut akan mengeluarkan nilai yang nantinya dijadikan pedoman atau patokan ANN untuk proses pelatihan pada sistem backpropagation.

Pada sistem cerdas yang digunakan adalah backpropagation dimana sistem ini merupakan sistem sederhana yang mampu mengolah data dengan proses yang cepat dan maksimal. Inputan data yang diperoleh dari GLCM akan dipakai pelatihan data. Nilai output GLCM meliputi homoginiti, energi, entropi dan kontras. Masing-masing diberikan nilai target berbeda. Seperti untuk inputan GLCM grade 1 target output adalah 1. Grade 2 target output adalah 0,5 dan grade 3 target output 0 . Target output dilihat dari derajat tingkat keabuannya. Inti sel semakin berbentuk dan kelihatan seragam seperti pada grade 1 maka derajat kebuannya tinggi dan target outputnya lebih tinggi daripada grade 2 dan grade 3 . Semakin banyak data yang dipakai pelatihan nilai akurasinya semakin tinggi. Sedangkan untuk data testing diambil 10 data saja mengingat data keseluruhan sebanyak 50 per masingmasing grading. Untuk output keluaran sistem cerdas ini adalah grade 1,2,3.

\section{KESIMPULAN DAN SARAN}

Berdasarkan hasil penelitian ini, dapat disimpulkan bahwa:

1. Hasil segmentasi citra sediaan histopatologi kanker mampu mengelompokkan citra sesuai dengan 
yang diinginkan untuk mengidentifikasi kanker payudara.

2. Akurasi pelatihan tertinggi didapatkan menggunakan variasi nilai parameter yang dihasilkan dari GLCM dan proses training data pada backpropagation yaitu 1 untuk learning rate, 10 buah neuron pada hidden layer, dan 10000 maksimum epoh.

Dari hasil penelitian dan pembahasan, berikut beberapa saran bagi penelitian mendatang :

1. Menambahkan detail diagnosa hasil keluaran nilai masing-masing pleumorfix, tubular formasi dan mitosis sehingga hasil diagnosa program lebih dipercaya.

Memuat kesimpulan yang diperoleh dan saran-saran untuk penelitian selanjutnya (jika ada).

\section{UCAPAN TERIMA KASIH}

Puji syukur kehadirat Allah SWT atas limpahan rahmat serta hidayah-Nya sehingga penulis dapat menyelesaikan tesis berjudul " Penentuan Grading Histopatologi Kanker Payudara Menggunakan Artificial Neural Network." Naskah tesis ini dikerjakan untuk memenuhi syarat kelulusan dan mendapat gelar Magister Teknik di Program Studi S-2 Teknobiomedik, Sekolah Pascasarjana Universitas Airlangga. Tesis ini diharapkan dapat bermanfaat bagi dunia kedokteran khususnya para dokter ahli Patologi Anatomi di Indonesia. Selain itu tesis ini dapat membantu adik-adik angkatan dalam menemukan topik-topik baru dalam melakukan penyusunan tesis.

Naskah tesis ini dapat diselesaikan dengan baik berkat bantuan dan dukungan dari semua pihak. Oleh karena itu, penulis mengucapkan terima kasih kepada:

1. Dr. Riries Rulaningtyas, ST.,MT selaku Pembimbing I yang telah sabar membimbing, mengarahkan dan memotivasi dalam penyusunan tesis.

2. Anny Setijo Rahaju,dr.,SpPA(K) selaku Pembimbing II yang telah memberikan judul penelitian dan mengarahkan dalam pengambilan data.

3. Dr. Suryani Dyah Astuti, S.SI., M.Si selaku Ketua Program Studi S2
Teknobiomedik Universitas Airlangga sekaligus Ketua Dewan Penguji.

4. Dr. Ir. Soegianto Soelistiono,M.Si. dan Dr. Khusnul Ain, ST, M.Si selaku penguji I dan II yang memberikan arahan dan masukan dalam penyusunan tesis ini.

5. Suami (Sugeng) dan anak-anakku (Hafizh Ahsan Fatoni dan Karinina Ferizkia) yang selalu memberikan motivasi dan do'a untuk keberhasilan studi ini.

6. Bu Yuni dan dr. Heru PPDS yang telah membantu dalam proses persiapan data dan pengambilan data.

7. Lelen, Limpat, Khusnul dan Leonard yang sudah membantu dipengerjaan program.

8. Para dosen S2 Teknobiomedik yang telah memberikan ilmu yang bermanfaat buat kami.

9. Teman-teman seperjuangan (Adi, Pandu, Basitha, Anggi) dan teman-teman yang sudah membantu dalam penyusunan penelitian tesis. Terima kasih atas kebersamaan dan kekeluargaanya

10. Teman-teman STIKES Insan Unggul Surabaya (Zufra Inayah, Diah dan Nourma Yunita) atas motivasi dan do'anya.

11. Para tenaga akademis pasca sarjana (Bu Sis, Bu Atik, Pak Dani, Pak Patmo dan Pak Yatno) yang telah membantu kami dalam semua persiapan pembelajaran, ujian dan hasil ujian.

12. Dan semua yang telah memberikan semangat dan doa yang tidak bisa disebutkan satu per satu.

\section{DAFTAR PUSTAKA}

Ellis IO, et all. Invasive breast carcinoma. In: Tavasolli FA, Devilee P. Pathology and Genetic of Tumours of the Breast and Female Genital Organs, WHO Classification of Tumours, IARC Press; 2003: 1819, 23-43.

Rosai J. The Breast, Rosai and Ackermans's Surgical Pathology, Volume two, Mosby; 2004(9): 910, 1797, 1802-18. 
Patten BM. Human Embryology, Mc Graw-Hill; Philadelphia; 2004(2): 240-41.

Schnitt SJ, Mills RR, Hanby AM, Oberman HA. The Breast. In: Mills SE, et all, 2004, Stenberg's Diagnostic Surgical Pathology, Volume IA, Lippincott Williams \& Wilkins; 2004(4): 330 -67.

Lester SC. The Breast. In: Kumar V, Abbas AK, Fausto N. Robbins and Cotran Pathologic Basis of Disease. Elsevier Saunders; Philadelphia; 2005(7): 1120, 1142-49.

Thor AD, Osunkoya AO. The Breast. In: Rubin E, Strayer DS. Farber. Editors. rubin's Pathology: Clinicopathologyc Fondation of Medicine. JB Lippincott Williams \& Wilkins; Philadelphia; 2008(5): 84253.

Montag A, Kumar V. The Female Genital System and Breast. In: Kumar V, Abbas AK, Fausto N, Mitchell RN. Robbins Basic Pathology. Saunders Elsevier; Philadelphia; 2007(8): 743-49.

Chandrasoma P, Taylor CR. The Breast, Concise Pathology, McGraw-Hill International Edition; 2001(3): 815-29.

Rosen PP. Invasive Mammary Carcinoma, Breast Pathology, Volume I, Lippincott; Philadelphia; 2001(2): 236 - 56.

Breast Cancer Genes and Inheritance, 2009 [cited on 2010, July 29]. Available from: http://www.familycancer.org/FamHi $\underline{\text { st.5tm. }}$.
Kissane J M. The Breast, Anderson's Pathology, Volume II, Mosby, 1990(9): 1726 - 48.

Sloane JP. The Breast, Biopsy Pathology of The Breast, Biopsy Pathology series 24, Arnold, 2001(24): 62 - 9.

Pettinato, Guido, Carlos J. Manivel, Invasif Micropapillary Carcinoma of the Breast, Am J Clin Pathol ; 2004, $121: 6: 854-66$.

Slide Apocrine Carcinoma of Breast, 2010 [cited on 2010, July 27]. Available from: http://www.webpathology.com/.

Adenoid cystic carcinoma, 2010 [cited on 2010, July 27]. Available from: http://www.wikipedia.com/.

Automated grading of breast cancer histopathology using cascaded ensemble with combination of multi-level image features, Tao Wana, Jiajia Caob, Jianhui Chenc, Zengchang Qinb,2016

Grading and Prognosis of Invasive Ductal Mammary Carcinoma by Nuclear Image Analysis in Tissue Sections, K. D. Kunze, G. Haroske, V. Dimmer, W. Meyer and F. Theissig, Institute ofPathological Anatomy, Medical Academy "Carl Gustav Carus'; Dresden, GDR, 1989

Grading in histopathology, Simon S Cross, Ksenija Benes, Timothy J Stephenson Robert F Harrison,2011

Histology image analysis for carcinoma detection and grading, Lei He, L. Rodney Long, Sameer Antani, George $\quad R$. Thoma,2011 
Histological Grading And Prognosis In Breast Cancer A Study Of 1409 Cases Of Which 359 Have Been Followed For 15 Years,H. J. G. Bloom And W. W. Richardson, From The Meyerstein Institute Of Radiotherapy And The Bland-Sutton Institute Of Pathology Of The Middlesex Hospital, London, $\mathrm{W}, 1957$

Nasser, S., Alkhadi, R. A Modifed Fuzzy K-means Clustering using Expectation maximization. University of Nevada Reno, Reno RV 89557, USA, hal 471,2008.

Paulus, E., Nataliani, N. Cepat mahir GUI Matlab. Penerbit Andi, Yogyakarta.2007.

Putra, D. Pengolahan Citra Digital. Penerbit Andi, Yogyakarta. 2010.

Anonim, 2008, Deteksi Kanker Leher Rahim Dan Kanker Payudara, http:// www.depkes.go.id/index.php option=news\&task=viewarticle\&sid $=2965,15$ September 2009

$\begin{array}{lr}\text { Optimasi Kinerja } & \text { Algoritma } \\ \text { Klasterisasi } \quad \text { K-Means } & \text { untuk } \\ \text { Kuantisasi Warna Citra } & \\ \text { Irwanto, Yudhi Purwananto dan Rully } \\ \text { Soelaiman,2012 }\end{array}$

